\title{
First Steps Towards Freedom: Prison Leave Across Europe
}

\section{Luc Robert $^{1}$ • Elena Larrauri ${ }^{2}$}

Published online: 7 July 2020

(C) Springer Nature B.V. 2020

The reintegration of ex-prisoners into society has been high on scientific and public agenda's in the last two decades. ${ }^{1}$ Since the late 1990s, policy makers and scientists have become increasingly aware of the inescapable fact that almost all prisoners come back to society at some point in time (notably, Petersilia 2003; Travis 2005; Travis \& Visher 2005).

This revival of attention for reintegration has also sparked new interests in release policies and practices. Debates about early release are usually focused on parole or conditional release, and on how they fare upon release at the moment prisoners re-enter society, (e.g. Padfield et al. 2010; e.g. Dünkel et al. 2018).

In this thematic issue, we want to call attention to prisoners' first forays into free society from within prison - prison leave. Throughout the issue, prison leave refers to types of release on temporary licence, for being allowed out for several hours, up to staying outside prison for more than one day, with a focus on preparing for reintegration.

Little is known about prison leave in Europe (and, we dare say, elsewhere too), although some pioneering texts have been written about it decades ago (e.g. Toch 1967; Van Zyl Smit 1988; Liebling 1989). For the most part though, prison leave has remained under the scientific radar. This is remarkable, to say the least. There are very good reasons why prison leave deserves separate scientific attention.

Our focus is on prison leave for prisoners in a closed regime. We think prison leave is particularly important in this case because it gives short-term goals, and it allows to divide the

\footnotetext{
${ }^{1}$ Conceptually, the term reintegration is mostly used in Europe, whereas in the USA, it is referred to as "re-entry", and in the UK, the term most often used is "resettlement" (e.g. Maruna 2006, p. 25).

Part of this introduction is based on the project Ejecución y supervisión de la pena: Calidad de la intervención, legitimidad y reincidencia supported by the Spanish Ministry of Economy and Competitiveness, Grant DER2015-64403-P and FEDER, UE; also supported by Ayudas a las acciones de dinamización "Redes de Excelencia": Desarrollo de un modelo criminológico y empírico de la política criminal - Acrónimo EmpiriC Financiado por MCIU-AEI (Ref. DER2017-90552-REDT).
}

Luc Robert

Luc.Robert@UGent.be

1 IRCP, Ghent University and visiting researcher, National Institute of Criminalistics and Criminology (NICC), Brussels, Belgium

2 Universitat Pompeu Fabra (UPF), Barcelona, Spain 
sentence and wait for the next prison leave to go out (this argument is derived from the idea of "marking time", in which prisoners differentiate and divide time; e.g. Cohen \& Taylor 1972, pp. 93-111). In another sense, prison leave contributes to achieving order in prison. Furthermore, prison leave may be helpful in countering or limiting negative effects of imprisonment, including social isolation and estrangement from one's family. And finally, prison leave represents a first important step for prisoners towards their reintegration into society, and in many occasions it is a required first step before being eligible for early release. Some studies have also looked at whether and how prison leave helps in reducing recidivism (e.g. Cheliotis 2008, 2009).

On a normative level, in Recommendation No. R(82) 16 on Prison Leave, the Committee of Ministers of the Council of Europe already sought "to establish a common European policy on prison leave" (Van Zyl Smit \& Snacken 2009, p. 321), referring to its importance as a bridge towards society and as a means to alleviating certain "pains of imprisonment" (see also the ECtHR Judgment Boulois v. Luxembourg, 3 April 2012).

So far, little is known about prison leave and whether and how it exists across Europe, whether it succeeds in obtaining its explicit (and implicit) objectives and how it links to conditional release or parole and to recidivism.

In this thematic issue, we invited scholars from all quarters of Europe to shed light on prison leave in their country. This thematic issue aims to inform readers about the divergences and convergences in prison release across Europe. The goal is to bring to the scientific arena (in its lingua franca) descriptions, scientific evidence and reports about the use and practices of prison leave from countries that are not always available to international readers.

Two main topics have emerged in the articles of this issue. The first topic is the use of discretion regarding the criteria that are used in the decision-making process. Criteria are often formulated on a normative basis ("the ought"), without any prior empirical assessment of their validity and reliability ("the is"). Certainly, more research would be desirable to convince that these criteria (for example paying compensation to the victim, or acknowledging one's offence) are relevant for reintegration, and are not only expression of criminological fads. Similarly, further research should be conducted about methods of decision-making in prison leave, ranging from highly case-based modes of decision-making up to the use of structured instruments, or combinations of both.

The second topic is the authority to grant prison leave. We find differences among the countries due to its particular legal tradition. Some countries tend to rely more on written law and leave scarce discretion to the prison administration and/or judge (especially when prison leave is automatically granted to prisoners). If the prison administration has the authority to decide, the reasons might lean towards order in prison, with prison leave potentially used as a "carrot" for good behaviour behind bars. Additionally, the further away the authority to decide upon prison leave, the less the decision-making authority will eventually "know" the prisoner who is being considered for prison leave. However, the more local and proximate the authority, the more this raises issues of uniformity in deciding over prison leave, with important differences in proportions of prison leave granted between similar prisons.

Several important normative questions are raised throughout the thematic issue, with each country providing different answers to them. These include the following: When is the best moment to grant prison leave: since the beginning of the sentence or at the end, or somewhere in between? Which should be the criteria? Who should decide over prison leave: the legislator, prison authorities (as part of the executive power) or the judiciary? Is it possible to structure discretion and up to what point? Should we aim for a system that (quasi-) automatically 
provides prison leave to prisoners (and excludes only the very exceptional cases)? All these conflicts, tensions and challenges are of course well known to prison scholars. Prison leave is just but one example and occasion to keep discussing them.

Finally, we also would like to hear the prisoner's voice, which since the pioneering research by Toch (1967) has been relatively absent. In any case, we hope readers will learn and enjoy getting to know this small institution which precedes and, in many cases, opens the early release procedures.

This Special Issue regarding the Spanish situation, as Larrauri (2020) explains, the institution of prison leave is well known among Spanish prisoners since half the prison population benefits from a prison leave. However, contrary to the law that foresees prison leave once a quarter of the sentence is served, according to research it is granted once three-quarters of the sentence has been served. Moreover, immigrants are usually excluded (only $21 \%$ enjoy a prison leave by the end, as opposed to $73 \%$ of nationals). In addition, the main problem of prison leave in Spain is the wide discretion that psychologists in particular have, and the fact that criteria like "acknowledging the offence" or "participating in treatment programs" might be experienced as unfair by the prisoner. Finally, in Spain, the authorities that grant prison leave are prison boards and judges, which often produces confusing results for prisoners. This reinforces the feeling of lack of clear criteria and procedure in relation to prison leave, which might also affect legitimacy in prison.

In her paper, Talini (2020) provides a description of the prison leave regulation in the Italian criminal system in order to bring out critical points and a questionable compatibility with the Italian Constitution that recognizes the principles of rehabilitation and the prohibition of inhuman treatments. The Prison Act (Law no. 354/1975) allowed prison leave only for woeful events occurring in the life of the detainee. However, "bonus leave"-introduced by further provision in Law no. 663/1986 - can be granted in order to foster family ties and cultural or work interests, but only to convicts who have maintained good behaviour whilst imprisoned and who are not labelled as "socially dangerous". The paper analyses the recent Italian prison system reform, which entered into force in October 2018, and its compatibility with the Italian Constitution.

As Keinänen et al. (2020) point out regarding the situation in Finland, prison leave was introduced into the Finnish legal system in 1971 with the aim to reduce negative effects of institutionalization and disadvantages caused by the length of the prison sentence. After the reform of prison legislation in 2006, the role of prison leave has become even more central. A prisoner can be granted a prison leave when two-thirds of the prison term have been served. However, during the past 10 years, prison leave "based on an important reason" has grown into the most common type of prison leave. This indicates a structural change from the rigid legal rules to a more flexible practice. In 2018, there were about 17,000 prison leave applications, and over 13,000 of those were granted, i.e. $79 \%$. The conditions were breached 466 times, which is $3.5 \%$ of all prison leaves. The most common breaches of prison leave conditions were returning from a prison leave after the set time limit or being under the influence of alcohol or drugs. Regarding the authority that grants them, a majority of prison leave applications are decided in the prisons.

Regarding Ukraine, Symkovych (2020) argues that prison leave use may also be controversial and uneven across jurisdictions. Since the collapse of the USSR, the former Soviet countries have been pursuing different criminal justice policies, liberalising some penal practices whilst retaining many punitive Soviet legacies. Whilst legally available, temporary leave for prisoners in closed prisons is almost never granted in this Eastern European country. 
Ukraine needs to reconcile the official rhetoric of rehabilitation and social reintegration of offenders and actual implementation of penal policies, and reverse the underlying requirements governing temporary prison leave and expand its use.

As Storgaard (2020) explains, the motivation for prison leave in the Danish penal system is the maintenance of positive contacts outside prison and for reasons of discipline because the risk of being discredited and missing out on prison leave is expected to have an effect on prisoners' compliance with the rules in prison. The authority that grants the permission or revocation of prison leave lies in the hands of the prison administration. It is argued that political intervention in the well-established division of power between legislation and discretionary power jeopardizes transparency in decision-making and puts access to justice for prisoners at risk. Over the last few decades, more prison leaves have been granted for occasional reasons, such as being seen by a doctor, rather than oriented in preparation for release, such as education. The regulation of prison leave and release on parole are interrelated, as the latter more or less directly depends on a successful period of regular prison leave. And it is argued that the decline in the total amount of prison leave and the increase in the total number of rejections of parole are directly and indirectly interrelated.

Durnescu and Poledna (2020) analyse the policy and legal framework around prison leave in Romania. The paper explores the historical evolution of prison leave in Romania, as a reward and the use of discretion. Their conclusion is that the decision-making process continues to allow too much discretion in relation to prison leave and this may create problems for procedural justice and legitimacy. Prison guards - those called to trigger the rewards procedure - enjoy vast amounts of unguided power and the appeal mechanisms are sometimes informal or inaccessible for prisoners. The article discusses some improvements that will make the practice of prison leave more predictable and just for the prisoners.

In France, Herzog-Evans (2020) explains that prison leave (permission) is awarded to prisoners by the Juge de l'application des peines (JAP) — sentence implementation judge - in the context of a multi-agency commission, which takes place in prison and comprises the governor, some guards, probation officers and the prosecutor. Prisoners can apply for no less than four different types of permissions. The allocation of permission raises two series of issues. The first issue pertains to the lack of due process principles governing the decisionmaking. Prisoners who apply for permissions have no "voice" (in Tyler's definition of the term in the legitimacy of justice-procedural justice sense) are not present at the commission's meeting and cannot be represented by an attorney. This limits prisoners' agency and their sense of justice. The second issue focuses on a forthcoming law reform that intends to allocate the power to grant permissions to prison governors. The rationale for permissions has so far been mostly about ensuring that prisoners' reentry process is prepared, that they can keep qualitative contacts with their loved ones and that they can be trusted in the outside world. In other words, permissions are about rehabilitation. Since the main interest of governors is to keep good order, one can expect that if they were transferred the decision-making power, they would shift from this reentry-rehabilitation focus to a safety-discipline one.

Robert et al. (2020) zoom in on prison leave decision-making. In Belgium, after a prisoner submits an application for prison leave, the prison director has to provide a written opinion about it, which is then sent on to the Service for the Management of Imprisonment (SMI), which decides whether a prisoner should obtain prison leave. Five years after implementing the 2006 Release Act, the Directorate General of Penitentiary Institutions mandated a national study of prison leave decision-making practices. The study showed that both key actors, prison directors and the SMI, used their own highly discretionary approach to decision-making. There 
was little transparency regarding the other actor's approach, fueling mutual misunderstanding and frustrations about the other actor's decisions. Since then, attempts have been made to structure discretionary decision-making. In this article, they go on to reconstruct steps in an ongoing process of structuring discretionary decision-making. These have led to an increased proportion of prison leaves being granted, with more concordance in decision-making between prison directors and staff at the SMI.

The Special Issue sheds light on prison leave as an often overlooked institution. The contributions in this Special Issue can be of interest to researchers in penology, practitioners and policy makers involved in prisons and penal policy more widely. The articles provide an important overview of prison leave and how it is being used across Europe. In terms of research, the contributions show that prison leave is in need of more attention, including a search for "good/best practices", more systematic research about the effectiveness of prison leave and how it links to desistance and reintegration. As for policy makers and practitioners, the accounts from several countries can give them new policy ideas and assist in reflecting about the use of prison leave as an important but as of yet mostly underused institution. Finally, we also hope that the normative issues raised in these papers will be taken into account when the time comes to elaborate a future European Recommendation on Prison Leave that helps guiding the policy of the different European countries.

\section{References}

Cheliotis, L. K. (2008). Reconsidering the effectiveness of temporary release: a systematic review. Aggression and Violent Behavior, 13(3), 153-168.

Cheliotis, L. K. (2009). Before the next storm: some evidence-based reminders about temporary release. International Journal of Offender Therapy and Comparative Criminology, 53(4), 420-432.

Cohen, S., \& Taylor, L. (1972). Psychological survival. The experience of long term imprisonment. New York: Vintage Books.

Dünkel, F., Pruin, I., Storgaard, A., \& Weber, J. (2018). Prisoner resettlement in Europe. London: Routledge.

Durnescu, I. \& Poledna, S. (2020). Prison leave in Romania and the power of street level bureaucrats. European Journal on Criminal Policy and Research, 26(2).

Herzog-Evans, M. (2020). French prison day leave and the rationale behind it: resocialisation or prison management. European Journal on Criminal Policy and Research, 26(2).

Keinänen, A., Kilpeläinen, M., Pajuoja, J. \& Tyni, S. (2020). Prison leave in Finland: legal and empirical fundamentals of an established practice. European Journal on Criminal Policy and Research, 26(2).

Larrauri, E. (2020). Reducing discretion in the administration of prison leave: in search of legitimacy. European Journal of Criminal Policy and Research, 26(2).

Liebling, A. (1989). Temporary release: getting embroiled with prisons. The Howard Journal of Crime and Justice, 28(1), 51-55.

Maruna, S. (2006). Who owns resettlement? Towards restorative re-integration. British Journal of Community Justice, 4(2), 23-33.

Padfield, N., van Zyl Smit, D., \& Dünkel, F. (2010). Release from prison. European policy and practice. Cullompton, Devon: Willan Publishing.

Petersilia, J. (2003). When prisoners come home. Parole and prisoner reentry. Oxford: University Press.

Robert, L., Mine, B., Maes, E. \& Jonckheere, A. (2020). Structuring discretion among Belgium's prison leave decision-makers. European Journal on Criminal Policy and Research, 26(2).

Storgaard, A. (2020). Prison leave in Denmark: how a tradition of combining rehabilitation with discipline developed into putting access to justice at risk. European Journal on Criminal Policy and Research, 26(2).

Symkovych, A. (2020). The eye of a needle: temporary prison leave in Ukraine. European Journal on Criminal Policy and Research, 26(2).

Talini, S. (2020). Prison leave in Italy: legislation and practical application. Is the Italian regulation on prison leave ensuring the constitutional purpose of punishment? European Journal on Criminal Policy and Research, 26(2). 
Toch, H. (1967). Prison inmates' reactions to furlough. Journal of Research in Crime and Delinquency, 4(2), 248-262.

Travis, J. (2005). But they all come back. Facing the challenges of prisoner reentry. Washington: The Urban Institute Press.

Travis, J., \& Visher, C. (2005). Introduction: viewing public safety through the reentry lens. In J. Travis \& C. Visher (Eds.), Prisoner reentry and crime in America (pp. 1-14). Cambridge: University Press.

Van Zyl Smit, D. (1988). Leave of absence for West German prisoners. The British Journal of Criminology, 28(1), 1-18.

Van Zyl Smit, D., \& Snacken, S. (2009). Principles of European prison law and policy. Penology and human rights. Oxford: University Press.

Publisher's Note Springer Nature remains neutral with regard to jurisdictional claims in published maps and institutional affiliations. 